\title{
Soil Quality Indicators as Affected by a Long Term Barley-Maize and Maize Cropping Systems
}

\author{
Barbara Manachini ${ }^{*}$, Anna Corsini ${ }^{2}$, Stefano Bocchi $^{2}$ \\ ${ }^{1}$ Dipartimento di Biologia Animale, Università di Palermo, Via Archirafi 18, 90123 Palermo, Italy \\ ${ }^{2}$ Dipartimento di Produzione Vegetale, Università di Milano, Via Celoria 2, 20133 Milano, Italy
}

Received: 18 November 2008. Accepted: 7 March 2009.

\begin{abstract}
Most soil studies aim a better characterization of the system through indicators. In the present study nematofauna and soil structure were chosen as indicators to be assess soil health as related to agricultural practices. The field research was carried out on the two fodder cropping systems continuous maize (CM, Zea mays L.) and a 3-year rotation of silage-maize - silage-barley (Hordeum vulgare L.) with Italian ryegrass (R3) and grain-maize maintained in these conditions for 18 years. Each crop system was submitted to two management options: 1) the high input level $(\mathrm{H})$, done as a conventional tillage, 2) the low input level (L), where the tillage was replaced by harrowing and the manure was reduced by $30 \%$.

The effects of the two different cropping systems was assessed on soil nematofauna and soil physic parameters (structure or aggregate stability). Comparison was made of general composition, trophic structure and biodiversity of the nematofauna collected in both systems. Differences in nematode genera composition and distribution between the two systems were also recorded. The monoculture, compared to the three year rotation, had a negative influence on the nematofauna composition and its ecological succession. The Structural Stability Index (SSI) values indicate that both the cropping systems had a negative effect on the aggregate stability.

The results indicate that nematofauna can be used to assess the effects of cropping systems on soil ecosystem, and therefore be considered a good indicator of soil health to integrate information from different chemical or physical indicators.
\end{abstract}

Key-words: soil health indicators, nematofauna, aggregate stability, cropping system.

\section{Introduction}

In agro ecosystems, conventional management practices e.g. tillage, distribution of chemicals, irrigation, organic mulch and fertilizers can be considered as sources of disturbance that have an impact on the soil system. In intensive cropping systems, where the soil is perturbed every year, several times in repeated phases, the disturbances may reduce the diversity of the soil fauna (Steen, 1983). The crop management, as a part of the cropping system, has complex effects on the soil physical, chemical and biological characteristics. The intensification level agricultural practices generally affects soil water content, aeration, rate of organic matter decomposition and release of nutrients, all having strong impact on soil health. The relations among abiotic and biotic components of the soil and the effects of agriculture on these two components (Wardle et. al, 2004; Pulleman et al., 2005; Tsiafouli et al., 2005) is still an important issue.

Nematodes are abundant and ubiquitous soil fauna; they represent a heterogeneous group that effect crop growth directly or indirectly as consumers of bacteria, fungi and other organisms, regulating decomposition and release of nutrients to the plant (Freckman, and Ettema, 1993). Any change in the soil habitat of nematodes could influence their food source or environment, affecting biodiversity and structure of the community. Nematofauna plays an important role in agro ecosystems and occupies a key position as primary and intermediate consumers in soil food webs; therefore, the study of the nematode community structure offers a

* Corresponding Author: Tel.: +39 091 6230170; Fax: +39 091 6230144. E-mail address: b.manachini@unipa.it 
powerful ecological tool for assessing soil disturbances and the effects of crops (Manachini, 2001). There has been an extensive assessment of their use as indicators of soil conditions, especially for their short-term response to environmental changes (Bongers, 1990; Ettema and Bongers, 1993; Yeates et al., 1993). Regarding the physical properties of the cultivated soils, aggregate stability and soil structure are considered as a key indicators of soil health (Arshad et al., 1996; Amézketa, 1999; Six et al., 1999; Duiker et al., 2003). Soil structure influences soil water movement and retention, erosion, crusting, nutrient recycling, root penetration and crop yield (Hermavan and Cameron, 1993; Langmaack, 1999).

The decline in soil structure, considered as a form of soil degradation (Chan et al., 2003), is often related to non appropriate land use and soil/crop management practices.

The main consequence of long-term intensive cultivation, especially under monoculture regime, is the degradation of soil structure, which can even reduce the effect of chemical fertilizers and affect soil fauna. Moreover, the resulting soil porosity conditions are often unfavourable to crop growth (Pagliai et al., 1995). To evaluate the impact of management practices on the soil environment it is necessary to quantify the modifications to the soil structure (Danielson and Sutherland, 1986).

Most of the studies have been done on shortterm effects, while the long-term (multi-year) effects of management practices on soil fauna (Yeates et al., 1993; Wardle et al., 2004; Rahman et al., 2007) and soil structure (Saggar, 2001) is not fully investigated. More information is needed, particularly over a range of cropping systems and environments, to demonstrate the effects of tillage and stubble management practices on the abundance and diversity of nematodes in cultivated soils (Rahman et al., 2007).

Long-term field experiments, even if more expensive, can provide long-term data sets, that can be used to develop mathematical models and give more information regarding sustainability of agricultural management and the effects on biodiversity (Johnston, 1997). We have chosen nematofauna and soil structure as key indicators for assessing soil health and quality.

Therefore the study aimed at: (a) analyzing the influences of different cropping systems maintained for a long period on the composi- tion of the nematode community and soil structure; (b) introducing these properties as good key indicators for assessing soil health and agromanagement.

\section{Materials and method}

\subsection{Area description and treatment details}

The experimental trial was located in Lodi, northern Italy $\left(45^{\circ} 19^{\prime} \mathrm{N}, 9^{\circ} 30^{\prime} \mathrm{E}, 81 \mathrm{~m}\right.$ elevation above sea level) and is representative of the alluvial Po Valley, on a sandy-loam soil of the mollic Hapludalf family with subacid $\mathrm{pH}$ (6.3), low in nitrogen and organic matter contents. The climate is typical of the lowlands of north-western Italy, with average annual rainfall of about 800 $\mathrm{mm}$ well distributed along the year, and average annual mean daily temperature of $12.5{ }^{\circ} \mathrm{C}$, January being the coldest month $\left(1.1^{\circ} \mathrm{C}\right)$ and July the hottest one $\left(22.9^{\circ} \mathrm{C}\right)$.

Two cropping systems were selected: (1) continuous grain maize (Zea mays L., CM); (2) a 3year rotation (R3): first year, autumn-sown barley (Hordeum vulgare L.) + spring-sown maize (both for silage); second year, Italian ryegrass (Lolium multiflorum L.) + spring sown maize (both for silage) and third year, grain maize. All the systems were continuously maintained for 18 years.

Each cropping system was submitted to two crop management (Tab. 1): the high level $(\mathrm{H})$, done as a conventional tillage, and the low level (L), in which the tillage was replaced by harrowing and the manure was reduced by $30 \%$ (for other details, see Onofrii et al., 1993). A further difference between $\mathrm{H}$ and $\mathrm{L}$ treatments was related to soil tillage before the autumn-sown crops. In the former treatment, the soil was ploughed to a depth of $30 \mathrm{~cm}$ and then rotarycultivated, while in the latter it was only rotarycultivated to a depth of $15 \mathrm{~cm}$. All maize crops, either for silage or grain, in both treatments were ploughed prior to sowing, and rotary-cultivated along the rows after the plant emergence, also to favour burial of nitrogen fertiliser (half of total amount) applied at the postemergence stage. Four surface irrigations, each of approximately $1000 \mathrm{~m}^{3} \mathrm{ha}^{-1}$ volume, were provided to the whole trial (both treatments). Time of sowing and other cultural practices were those considered conventional for the region.

A split-plot complete randomized block de- 


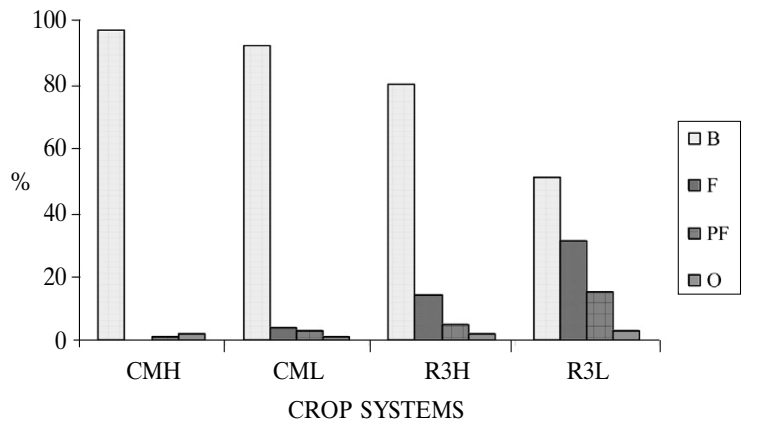

Figure 1. Trophic group composition (\%) in high input of continuous maize $(\mathrm{CMH})$, low input of continuous maize (CML), high input of 3 year rotation $(\mathrm{R} 3 \mathrm{H})$ and low input of 3 year rotation (R3L); B bacterial feeders, $F$ fungal feeders, $\mathrm{PF}$ plant feeders and $\mathrm{O}$ omnivores.

sign was adopted with three replications, the main plots being represented by the input level (High vs Low) and the sub-plots by the cropping system (CM vs R3). The trial included 12 plots ( 3 crop-phases x 3 blocks $\times 2$ input levels), each measuring $60 \mathrm{~m}^{2}(6 \times 10 \mathrm{~m})$.

\subsection{Soil properties and nematofauna}

Soil samples were collected in October 2003 from $0-20 \mathrm{~cm}$ depth in 12 plots, 6 of $\mathrm{CM}$ and 6 of R3. Five sub samples from each plot in a zigzag pattern using a cylindrical core sampler were taken for nematodes while one sample from each plot using a shovel for chemical analysis and soil structural stability index determination (SSI). Soil Total Nitrogen (TN) and Total Organic Carbon (TOC) concentrations were determined by dry combustion using a Carlo Erba NA 1500 CNS Analyzer. Soil water $\mathrm{pH}$ in a 1:2.5 dispersion was measured with deionized water potenziometrically.

Nematodes were extracted from the soil with a modification of the Baermann funnel method (Cairns, 1960). From the total sample per plot (1 $\mathrm{kg})$ two replicated sub-samples, each of $150 \mathrm{~g}$ were processed. After counting the total number of nematodes in each sample, 120 nematodes were picked out randomly, transferred to an evaporation series of De Grisse solutions, mounted on slides and identified at genus level, using a microscope (Zeiss) at 100x magnification.

Communities in these cropping systems were compared, using different biodiversity indices: Maturity Index (MI), Shannon-Wiener (H'), Hill diversity numbers (No, N1, N2, Ninf), Simpson Diversity Index and Pielou Index (J').

Soil aggregate stability was determined by wet sieving with mechanic vertical oscillation.

Table 1. Crop management practices, including levels of nutrients, weed control (W) and soil tillage methods high in high $(\mathrm{H})$ and low $(\mathrm{L})$ input submitted to continuous maize $(\mathrm{CM})$ and 3year rotation (R3).

\begin{tabular}{|c|c|c|c|c|c|c|c|c|c|c|c|c|c|c|}
\hline \multicolumn{2}{|c|}{ Input Rotation } & \multirow{2}{*}{$\begin{array}{l}\text { Crop system } \\
1^{\text {st }} \text { Harvest }\end{array}$} & \multicolumn{7}{|l|}{$1^{\text {st }}$ Harvest } & \multicolumn{5}{|l|}{$2^{\text {nd }}$ Harvest } \\
\hline & & & $2^{\text {nd }}$ Harvest & Tillage & Fertiliser & $\begin{array}{l}\mathrm{N} \\
(\mathrm{kg}\end{array}$ & $\begin{array}{l}\mathrm{P}_{2} \mathrm{O}_{5} \\
\left.\mathrm{ha}^{-1}\right)\end{array}$ & $\mathrm{K}_{2} \mathrm{O}$ & W & Tillage & Fertiliser & $\begin{array}{l}\mathrm{N} \mathrm{P}_{2} \mathrm{O}_{5} \\
\left(\mathrm{~kg} \mathrm{ha}^{-1}\right)\end{array}$ & $\mathrm{K}_{2} \mathrm{O}$ & W \\
\hline \multirow[t]{6}{*}{$\mathrm{H}$} & $\mathrm{CM}$ & grain maize & - & Plough+ & $\begin{array}{l}\text { Mineral } \\
\text { org. }(* * *)\end{array}$ & 250 & 100 & 100 & $4(*)$ & & & & & \\
\hline & R3 & grain maize & - & Plough+ & Mineral & 250 & 100 & 100 & $4(*)$ & & & & & \\
\hline & & italian & silage & $\begin{array}{l}\text { Rotary-cult. } \\
\text { Plough+ }\end{array}$ & Mineral & 150 & 100 & 120 & & Plough+ & Mineral & 250100 & 100 & $4(*)$ \\
\hline & & ryegrass & maize & Rotary-cult. & & & & & & Rotary-cult. & Manure & 160100 & 100 & \\
\hline & & silage & silage & Plough+ & Mineral & 120 & 100 & 120 & $3(* *)$ & Plough+ & Mineral & 250100 & 100 & $4(*)$ \\
\hline & & barley & maize & Rotary-cult. & & & & & & Rotary-cult. & Manure & 160100 & 100 & \\
\hline \multirow[t]{7}{*}{$\mathrm{L}$} & $\mathrm{CM}$ & grain maize & - & $\begin{array}{l}\text { Plough+ } \\
\text { Rotary-cult. }\end{array}$ & $\begin{array}{l}\text { Mineral } \\
\text { org. }(* * *)\end{array}$ & 175 & 70 & 70 & $3(*)$ & & & & & \\
\hline & $\mathrm{R} 3$ & grain maize & - & Plough+ & Mineral & 175 & 70 & 70 & $3(*)$ & & & & & \\
\hline & & & & Rotary-cult. & & & & & & & & & & \\
\hline & & italian & silage & Rotary- & Mineral & 105 & 70 & 84 & & Plough+ & Mineral & $175 \quad 70$ & 70 & $3(*)$ \\
\hline & & ryegrass & maize & cultivated & & & & & & Rotary-cult. & Manure & 11270 & 70 & \\
\hline & & silage & silage & Rotary- & Mineral & 84 & 70 & 84 & $2(* *)$ & Plough+ & Mineral & $175 \quad 70$ & 70 & $3(*)$ \\
\hline & & barley & maize & cultivated & & & & & & Rotary-cult. & Manure & 11270 & 70 & \\
\hline
\end{tabular}

(***) Ploughing in corn stubbles.

(*) metolachlor + terbutilazine.

(**) methabenthiazuron. 
Table 2. Abundance of nematodes in $100 \mathrm{~g}$ of soil collected from high $(\mathrm{H})$ and low (L) inputs of continuous grain maize (CM) and 3 year rotation (R3); c-p (colonizer-persister) value.

\begin{tabular}{|c|c|c|c|c|c|c|}
\hline \multirow[t]{2}{*}{ Family } & \multirow[t]{2}{*}{ Genus } & \multirow[t]{2}{*}{$c-p$} & \multicolumn{2}{|c|}{$\mathrm{CM}$} & \multicolumn{2}{|c|}{ R3 } \\
\hline & & & $\mathrm{H}$ & $\mathrm{L}$ & $\mathrm{H}$ & $\mathrm{L}$ \\
\hline \multirow[t]{4}{*}{ Rhabditidae } & Rhabditis & 1 & 74.36 & 43.85 & 0.49 & 0.34 \\
\hline & Protorhabditis & 1 & 137.70 & 115.76 & 0.00 & 0.00 \\
\hline & Prodontorhabditis & 1 & 2.75 & 0.00 & 0.25 & 1.68 \\
\hline & Pelodera & 1 & 19.28 & 33.33 & 0.49 & 1.01 \\
\hline Plectidae & Plectus & 2 & 13.77 & 0.00 & 4.92 & 0.67 \\
\hline Monhysteridae & Monhystera & 2 & 0.00 & 0.00 & 0.00 & 0.34 \\
\hline \multirow[t]{2}{*}{ Panagrolaimidae } & Panagrolaimus & 1 & 0.00 & 1.75 & 1.47 & 1.34 \\
\hline & Panagrellus & 1 & 0.00 & 0.00 & 0.25 & 0.00 \\
\hline Anoplostomidae & Anoplostoma & 5 & 2.75 & 0.00 & 0.98 & 0.67 \\
\hline Teratocephalidae & Teratocephalus & 3 & 30.30 & 5.26 & 6.14 & 6.05 \\
\hline \multirow[t]{4}{*}{ Cephalobidae } & Cephalobus & 2 & 44.07 & 3.51 & 6.88 & 6.72 \\
\hline & Acrobeloides & 2 & 0.00 & 0.00 & 1.23 & 1.01 \\
\hline & Acrobeles & 2 & 0.00 & 0.00 & 0.00 & 0.67 \\
\hline & Chiloplacus & 2 & 0.00 & 0.00 & 0.00 & 0.34 \\
\hline \multirow[t]{2}{*}{ Aphelenchidae } & Aphelenchus & 2 & 0.00 & 3.93 & 3.93 & 9.41 \\
\hline & Aphelenchoides & 2 & 0.00 & 7.02 & 0.00 & 3.34 \\
\hline \multirow[t]{3}{*}{ Tylenchidae } & Tylenchus & 2 & 0.00 & 7.02 & 0.00 & 1.01 \\
\hline & Filenchus & 2 & 0.00 & 0.00 & 0.00 & 1.01 \\
\hline & Psilenchus & 2 & 0.00 & 0.00 & 0.25 & 1.01 \\
\hline Belonolaimidae & Tylenchorhynchus & 3 & 0.00 & 0.00 & 0.00 & 1.01 \\
\hline Hoplolaimidae & Helicotylenchus & 3 & 0.00 & 0.00 & 0.74 & 0.00 \\
\hline Pratylenchidae & Pratylenchus & 3 & 2.75 & 0.00 & 0.49 & 2.02 \\
\hline Discolaimidae & Discolaimus & 5 & 5.51 & 0.00 & 0.00 & 0.00 \\
\hline \multirow[t]{2}{*}{ Dorylaimidae } & Mesodorylaimus & 4 & 2.75 & 0.00 & 0.25 & 0.67 \\
\hline & Prodorylaimus & 4 & 0.00 & 1.75 & 0.00 & 0.00 \\
\hline Qudsianematidae & Eudorylaimus & 4 & 0.00 & 0.00 & 0.25 & 0.34 \\
\hline Aporcelaimidae & Aporcelaimus & 5 & 0.00 & 0.00 & 0.00 & 0.34 \\
\hline
\end{tabular}

The apparatus was equipped with vertical supports to which the 6 sieves with $0.2 \mathrm{~mm}$ mesh opening were fixed. The samples were subjected to vertical alternative motion with a stroke of 3 $\mathrm{cm}$ and a frequency of $30 \mathrm{~min}^{-1}$ for 30 minutes.

Two pre-treatments were applied before wet sieving: (a) air-dried soil rapidly submerged in water (slaked treatment); (b) air-dried soil prewetted with ethanol to test the wet mechanical cohesion of aggregates independently of slaking.

Air-dried and gently broken soil was passed through a $2 \mathrm{~mm}$ sieve to separate the $1-2 \mathrm{~mm}$ fraction (Kemper and Rosenau, 1986) for analysis. Then seven grams of latter (air dried or prewetted with ethanol) was submerged in $250 \mathrm{~cm}^{3}$ of deionized water for $30 \mathrm{~min}$, then transferred to sieves previously dipped in deionized water and subjected to a vertical oscillating movement (Cavazza and Linsalata, 1969). The remaining aggregates were oven dried at $105^{\circ} \mathrm{C}$ and subordinate to dispersion solution (40 g sodium hexametaphosphate and $10 \mathrm{~g}$ sodium carbonate/Liter) for coarse sand determination. The soil Structural Stability Index (SSI) of determined for each treatment was determined according to Pagliai et al. (1997):

$$
\text { SSI }=\frac{\begin{array}{c}
\text { Weight aggregates after sieving } \\
- \text { weight coarse sand }
\end{array}}{\begin{array}{c}
\text { Weight aggregates before sieving } \\
\text { - weight coarse sand }
\end{array}} \times 100
$$

After the required transformations (i.e nematode abundance was transformed to $\log (x+1))$ the data were statistically analysed (ANOVA), using the GLM procedure of SPSS statistical package (version 14.0 for Windows) and protected LSD test at a $95 \%$ level of confidence.

\section{Results}

\subsection{Nematofauna}

A total of 5700 nematodes were collected, but there was a quite different abundance among 
the crop systems. In $\mathrm{CMH}$ there were 333 nematodes in $100 \mathrm{~g}$ of soil, while in CML 222/100 $\mathrm{g}$; in $\mathrm{R} 3 \mathrm{H}$ nematodes were $29 / 100 \mathrm{~g}$ and in $\mathrm{R} 3 \mathrm{~L}$ $41 / 100$ g. Comparing the two systems, the trophic structure was extremely simple in $\mathrm{CM}$ in which less selective and sensitive genera were recorded (Tab. 2). In each ecosystem the dominant trophic group was bacterial feeders; however, the in CM were earlier colonizers, while the ones in R3 were second colonizers. The largest total number of bacterial-feeding nematodes was found in both inputs of CM.

In total, 29 genera belonging to 16 families were recorded from each input of $\mathrm{CM}$ and $\mathrm{R} 3$. The average of the abundance for each taxon is shown in Table 2.

In $\mathrm{CM}$ the bacterial feeders were dominated by members of the family Rhabditidae of which the genus Protorhabditis was more abundant in CML than in $\mathrm{CMH}$ and it was not recorded in both inputs R3. In this latter system, the bacterial feeders with c-p of 2 or 3 were more abundant in the high input; in the R3L Aphelenchus was the dominant genus.

The abundance of the genera Protorhabditis and Aphelenchus was statistically different $(\mathrm{P}<$ 0.05) in CM and R3, highlighting the effect of the different cropping systems. The effect of the agronomic input was evident only in the case of the rotation where the abundance of Aphelenchus and Aphelenchoides was statistically different $(\mathrm{P}<0.01)$.

Plant feeders were $5 \%$ of the nematode community in the high input of R3 and $15 \%$ of the total in the low input. Only one genus of plant feeders in each input of CM was record-

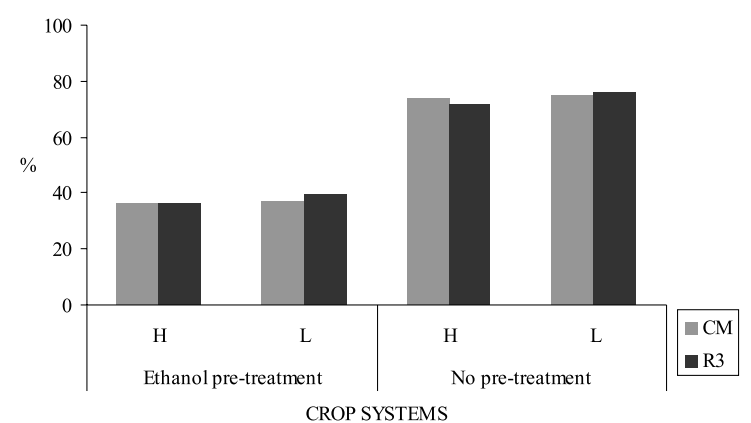

Figure 2. Soil Structural Stability index (SSI) in high $(\mathrm{H})$ and low (L) input of continuous grain maize $(\mathrm{CM})$ and 3 year rotation $(\mathrm{R} 3)$.
Table 3. Diversity indices for nematode communities from high $(\mathrm{H})$ and low $(\mathrm{L})$ inputs of continuous grain maize (CM) and 3 year rotation (R3). MI = Maturity index; $\mathrm{H}^{\prime}=$ Shannon-Wiener diversity index; N0-Ninf = Hill's numbers; J' = Pielou index.

\begin{tabular}{lrrrr}
\hline CM & \multicolumn{4}{c}{ R3 } \\
\cline { 2 - 5 } & H & L & H & L \\
\hline MI & 1.49 & 1.16 & 2.29 & 2.31 \\
H' & 0.80 & 0.67 & 0.93 & 1.10 \\
N0 & 12 & 10 & 16 & 22 \\
N1 & 1.75 & 1.59 & 1.91 & 2.14 \\
D & 0.22 & 0.32 & 0.16 & 0.12 \\
N2 & 4.47 & 3.11 & 6.42 & 8.46 \\
Ninf & 2.44 & 1.91 & 4.2 & 4.36 \\
J' & 0.75 & 0.62 & 0.77 & 0.82 \\
\hline
\end{tabular}

Table 4. Physical-chemical attributes of high $(\mathrm{H})$ and low (L) inputs of continuous grain maize $(\mathrm{CM})$ and 3 year rotation (R3).

\begin{tabular}{lcccc}
\hline & \multicolumn{2}{c}{$\mathrm{CM}$} & \multicolumn{2}{c}{$\mathrm{R} 3$} \\
\cline { 2 - 5 } & $\mathrm{H}$ & $\mathrm{L}$ & $\mathrm{H}$ & $\mathrm{L}$ \\
\hline $\mathrm{pH}$ & 6.12 & 6.33 & 6.37 & 6.35 \\
Total Organic Carbon (\%) & 0.97 & 0.96 & 1.05 & 0.93 \\
Total Nitrogen (\%) & 0.09 & 0.09 & 0.09 & 0.08 \\
\hline
\end{tabular}

ed: in CMH Pratylenchus in CMH and $T y$ lenchus in CML.

The biodiversity indices showed differences in the structure and biodiversity of both cropping systems (Tab. 3).

The minimum values of the biodiversity indices were recorded in both the input of $\mathrm{CM}$ and the maximum values were recorded in both the input of R3. The minimum value of the Maturity index was recorded in CML and the maximum in R3L.

\subsection{Soil properties}

Chemical properties are shown in Table 4. The $\mathrm{pH}$ was sub acid and the content of organic matter ranged from $1.6 \%$ to $1.8 \%$. The ratio $\mathrm{C} / \mathrm{N}$ was quite comparable with a maximum in $\mathrm{CML}$ and a minimum in $\mathrm{R} 3 \mathrm{H}$.

The results of the soil structure analysis are shown in Figure 2 where thy are presented as SSI.

Without pre-treatment (the right part of the figure) SSI appeared lower in both cropping systems than with ethanol pre-treatment. In fact with no pre-treatment the values never exceeded $40 \%$ while with pre-wetting with ethanol, by 
reducing slaking effect, the values were higher than $70 \%$. The highest value was recorded for $\mathrm{R} 3 \mathrm{~L}$ while the lowest for $\mathrm{R} 3 \mathrm{H}$.

\section{Discussion}

Intensive agriculture represented a great disturbance that should affect the heterogeneity of the below-ground soil food web and be reflected in the nematode community and in the soil structure. The agroecosystems studied had remained the some since 1985, and the two crop systems were present every year. Our results confirm that long term conventional intensive tillage and management not only worse the physical properties of the soils, as reported by Pagliai et al. (1995), but also the soil fauna community and therefore the soil biodiversity.

The diversity indices show differences between monoculture and rotation. Nematode abundance was higher in both inputs of CM compared to R3, highlighting that the differences could be due to the type of crop. Rahaman et al. (2007) found that rotation of wheat with lupin was more favourable for the population abundance of free-living nematodes than continuous wheat, irrespective of tillage and stubble management practices. Plant-parasitic nematodes were comparatively low in the rotated crops sequence suggesting biological control mechanisms (e.g. improvement of soil quality and conditions, abundance of free-living nematodes and other microbes in the rhizosphere areas, etc.) may have occurred (Rahaman et al., 2007). The very low abundance in CM of the omnivores/predators nematodes was in accordance with Niblack and Bernard (1985) who suggested that the low presence of this trophic group could indicate an unstable environment. Freckman and Ettema (1993) showed that trophic groups are very sensitive to agricultural practices that strongly disturb the soil, and this effect is clear in our study. The dominance of bacterial feeders with c-p value equal to 1 in $\mathrm{CM}$ indicates an initial ecological succession stage in the development of these ecosystems, due to conventional practices. The response of bacterial feeders observed in this study is in accordance with results found by Wasilewska (1979), who associated the largest population of bacterial-feeding nematodes with conventional tillage.
Our results support the on regarding the role of nematodes and the decomposition dynamics of the nutrients in soil of Coleman et al. (1984) and Goede et al. (1993). These authors found also an increase of earlier colonizer genera, especially bacterial feeders, such as the genus Protorhabditis, after disturbance due to conventional tillage and during the first stages of colonization. Saggar (2001) studied nematofauna in a monocolture corn field for 16 years and recorded that the family Rhabditidae was dominant and H' was low. We found that this genus was present only in the maize monocolture.

Nematode communities in both inputs of R3 seemed to be less stressed those the ones present in both inputs of CM. The dominance of nematodes with c-p 2 in R3 indicates that communities were in a progressive successional stage. In $\mathrm{R} 3 \mathrm{H}$ second colonisers, mainly the genus Cephalobus were dominant, in accordance with Griffiths et al. (1991), who noted an increase of abundance of bacteriofagous more sensitive in the rhizosphere of barley. Moreover, our results show that in R3L Aphelenchidae was the most abundant family. This shift from bacterial feeders to fungivores may be attributed to lower disturbance due to the low input.

Nematode communities recorded in $\mathrm{CM}$ had less biodiversity and they were more disturbed and badly structured. Our results confirm that $\mathrm{CMH}$ is extremely stressing for soil and tends to decrease biodiversity, being all the indices of trophic structure and community similar to a first colonisers community, while R3L is less stressful.

Regarding the soil aggregate stability, ethanol pre-treatment significantly increased the SSI compared with no pre-treatment to reduce slaking effect. The average of SSI to continuous maize and R3 has respectively a value of $36.79 \%$ and $38.04 \%$. Other cropping systems present in the same experimental field, such as permanent meadow or rotate meadow, showed value over $65 \%$ and $45 \%$, respectively, (data not yet published). As suggest by Giardini (1992), values smaller than under $40 \%$ represent a low aggregate stability and therefore, a poor soil structure for sustaining agricultural productivity and for preserving environmental quality (Amézketa, 1999). Our results are comparable with the observations of Pagliai et al. (1995), who comparing two soils (silt-loam and clay) for 
10 years with the same rotation (maize wheat) and two tillage management (conventional and minimum tillage similar this work) to test soil physical characteristics (porosity, aggregate stability, water content) found the aggregate stability in conventional tillage greater in minimum than conventional tillage.

\section{Conclusions}

In the present study different cropping systems maintained for a long period were monitored in order to detect the impact on the soil health through two key indicators: nematodes and aggregate stability. Two popular intensive fodder systems in Po River Valley (Northern Italy) at different input levels were studied by using the above indicators.

The Structural Stability Index with or without pre-treatments did not show any difference among the cropping systems and the intensification level. The ethanol pre-treatments reduced the slaking effect. Excessive breakdown of soil aggregates due to intensification of rotation and tillage (once or twice in CM and R3 respectively) caused a low degree of stability of aggregation influencing soil structure and relative properties.

Chemical attributes did not seem able to show differences of impact of the cropping systems with quite a high level of stress. Instead, nematofauna resulted to be able to underline differences even in those environmental soil conditions highly stressed, with similar management so that it is possible to consider it as an integrative bioindicator suitable for evaluating the soil health and/or the crop management.

\section{Acknowledgements}

The Authors wish to express gratitude to L. Borrelli and C. Tomasoni of ISCF Istituto Sperimentale per le Colture Foraggere for their assistance, Sergio Frigeni and Simona Landi for their support in field and in laboratory. This research was partially supported by MIUR year 2007 Grant.

\section{References}

Amézketa E. 1999. Soil aggregate stability: a review. J. Sust. Agric., 14:83-151.

Arshad M.A., Lowery B., Grossman B. 1996. Physical tests for monitoring soil quality. In: Doran J.W., Jones
A.J. (eds.): Methods for assessing soil fertility. Soil Science Society of America, special publication. Vol. 49:123-142. Soil Science Society of America, Madison, USA.

Bongers T. 1990. The maturity index: an ecological measure of environmental disturbance based on nematode species composition. Oecologia, 83:14-19.

Cairns E.J. 1960. Methods in nematology. In: Sasser J.N.., Jenkins W.R. (eds.): Nematology, Fundamentals and Recent Advances with Emphasis on Plant Parasitic and Soil Forms, 33-84. University of North Carolina Press, Chapel Hill, USA.

Cavazza L., Linsalata D. 1969. Misura della stabilità di struttura del terreno. Riv. Agron., 3:50.

Chan K.Y., Heenan D.P., So H.B. 2003. Sequestration of carbon and changes in soil quality under conservation tillage on light textured soils in Australia: a review. Aust. J. Exp. Agric., 43:325-334.

Coleman D.C., Cole C.V., Elliot E.T. 1984. Decomposition, organic matter turnover, and nutrient dynamics in agroecosystems. In: Lowrance R., Stinner B.R., House G.J. (eds.): Agricultural Ecosystems. Unifying Concepts, 83-104. Wiley, New York, USA.

Danielson R.E., Sutherland P.L. 1986. Porosity. In: Klute A. (ed.): Methods of Soil Analysis. Part I. Physical and mineralogical methods, 443-461. Agronomy, 9. ASA and SSSA. Madison, WI, USA.

Duiker S.W., Rhoton F.E., Torrent J., Smeck N.E., Lal R. 2003. Iron (hydr)oxide crystallinity effects on soil aggregation. Soil Sci. Soc. Am. J., 67:606-611.

Ettema C.H., Bongers T. 1993. Characterisation of nematode colonisation and succession in disturbed soil using the Maturity Index. Biol. Fert. Soils., 16:79-85.

Freckman D.W., Ettema C.H. 1993. Assessing nematode communities in agroecosystems of varying human intervention. Agric. Ecos. Env., 45:239-261.

Giardini L. 1992. Agronomia generale, ambientale e aziendale. Patron Editore, Bologna.

Goede R.G.M., Bongers T., Ettema C.H. 1993. Graphical presentation and interpretation of nematode community structure: c-p triangles. Med. Fac. Landbouww. Univ. Gent, 58:73-750.

Griffiths B.S., Young I.M., Boag B. 1991. Nematodes associated with the rizhosphere of barley (Hordeum vulgare L.). Pedobiologa, 35:265-272.

Hermavan B., Cameron K.C. 1993. Structural changes in a silt loam under long-term conventional or minimum tillage. Soil Till. Res., 26:139-150.

Johnston A.E. 1997. The value of long-term field experiments in agricultural, ecological, and environmental research. Adv. Agron., 59:291-333.

Kemper W.D., Rosenau R.C. 1986. Aggregate stability and size distribution. In: Klute A. (ed.): Methods of Soil Analysis. Part I. Physical and mineralogical methods, 425-442. Agronomy, 9. ASA and SSSA, Madison, WI, USA. 
Langmaack M. 1999. Earthworm communities in arable land influenced by tillage, compaction and soil. $\mathrm{Z}$. Kol. Natursch., 8:11-21.

Manachini B. 2001. Nematode diversity in vineyard soil under different agricultural management regimes. IOBC wprs Bulletin, 24:253-261.

Niblack T.L., Bernard E.C. 1985. Nematode communities structure in dogwood maple, and peach nurseries in Tennessee. J. Nematol., 17:126-131.

Onofrii M., Tomasoni C., Borrelli L. 1993. Confronto tra ordinamenti cerealicolo-foraggeri, sottoposti a due livelli di input agrotecnico, nella pianura irrigua lombarda. Riv. Agron., 27:160-172.

Pagliai M., Raglione M., Panini T., Maletta M., La Marca M. 1995. The structure of two alluvial soils in Italy after 10 years of conventional and minimum tillage. Soil Till. Res., 34:209-223.

Pagliai M., Torri D., Patruno A. 1997. Metodi di analisi fisica del suolo. Franco Angeli, Roma, parte V, 7-9.

Pulleman M.M., Six J., Marinissen J.C.Y., Jongmans A.G. 2005. Earthworms and management affect organic matter incorporation and microaggregate formation in agricultural soils. Appl. Soil Ecol., 29:1-15.

Rahman L., Chan K.Y., Heenan D.P. 2007. Impact of tillage, stubble management and crop rotation on ne- matode populations in a long-term field experiment. Soil Tillage Res., 95:110-119.

Saggar S. 2001. Soil Science at the cross roads - Norman Taylor Memorial Lecture 2001 New Zeal. Soil News, 49:132-139.

Six J., Elliott E.T., Paustian K. 1999. Aggregate and soil organic matter dynamics under conventional and notillage systems. Soil Sci. Soc. Am. J., 63:1350-1358.

Steen E. 1983. Soil animal in relation to agricultural practices and soil productivity. Swedish J. Agric. Res., 13:157-165.

Tsiafouli M.A., Kallimanis A.S., Katana E., Stamou G.P., Sgardellis S.P. 2005. Responses of soil microarthropods to experimental short-therm manipulations of soil moisture. Appl. Soil Ecol., 29:17-26.

Wardle D.A., Bardgett R.D., Klironomos J.N, Satala H., van der Putten W.H., Wall D.H. 2004. Ecological linkages between aboveground and belowground biota. Science, 304:1629-1633.

Wasilewska L. 1979. The structure and function of soil nematode communities in natural ecosystems and agrocenoses. Polish Ecological Studies, 5:97-145.

Yeates G.W., Bongers T., De Goede R.G.M., Freckman D.W., Georgieva S.S. 1993. Feeding Habits in soil nematode families and genera - An outline for soil ecologist. J. Nematol., 25:315-331. 